\title{
Pengaruh Variasi Konsentrasi Ekstrak dan Variasi Volume Ekstrak Terhadap Karakteristik Nanopartikel Ikan Haruan (Channa striata) Asal Kalimantan Selatan
}

Dina Rahmawanty*, Ridwan Ali Muhammad, Ratnapuri Prima Happy, Kartinah Nani

\author{
Program Studi Farmasi, Fakultas Matematika dan Ilmu Pengetahuan Alam, Universitas Lambung Mangkurat, \\ Banjarmasin 70714 \\ *Email korespondensi : dinarahmawanty@ulm.ac.id
}

(Submit 15/03/2019, Revisi 05/09/2019, Diterima 20/12/2019)

\begin{abstract}
Abstrak
Ikan Haruan (Channa striata) mengandung asam amino esensial dan protein yang dapat membantu proses penyembuhan luka, memiliki sifat hidrofilik dan stabilitas yang rendah. Penelitian ini bertujuan untuk menentukan pengaruh variasi konsentrasi ekstrak ikan haruan dan variasi volume ekstrak ikan haruan terhadap karakteristik nanopartikel yang dihasilkan yaitu ukuran partikel, distribusi ukuran partikel, indeks polidispersitas, dan pengendapan. Metode pembuatan nanopartikel pada penelitian ini menggunakan metode gelasi ionik dengan menggunakan ekstrak ikan haruan sebagai zat aktif dan kitosan serta NaTPP sebagai agen sambung silang. Rasio volume kitosan : tripolipospat yang digunakan adalah 5:1. Variasi konsentrasi ekstrak yang digunakan adalah $2 \mathrm{mg} / \mathrm{ml}, 4 \mathrm{mg} / \mathrm{ml}$, dan $6 \mathrm{mg} / \mathrm{ml}$. Variasi volume ekstrak yang ditambahkan adalah $1 \mathrm{ml}$ dan $5 \mathrm{ml}$. Hasil yang diperoleh penambahan $1 \mathrm{ml}$ volume ekstrak ikan haruan dengan variasi konsentrasi $2 \mathrm{mg} / \mathrm{ml}, 4 \mathrm{mg} / \mathrm{ml}$, dan $6 \mathrm{mg} / \mathrm{ml}$ menghasilkan nanopartikel dengan ukuran partikel $318,5 \mathrm{~nm}, 361,1 \mathrm{~nm}$, dan $403,5 \mathrm{~nm}$. Terdapat peningkatan ukuran nanopartikel ikan haruan pada penambahan $5 \mathrm{ml}$ volume ekstrak ikan haruan yaitu 1679,3 nm, $1114 \mathrm{~nm}$ dan $1554 \mathrm{~nm}$. Distribusi ukuran partikel berdasarkan nilai indeks polidispersitas semua formula memiliki nilai Pdi $<0,7$ menunjukkan bahwa nanopartikelikan haruan yang dihasilkan monodisperse. Pada pengamatan kejernihan secara visual selama 7 hari tidak terjadi pengendapan. Kesimpulan yang dapat diperoleh dari penelitian ini adalah variasi konsentrasi ekstrak dan variasi volume ekstrak ikan haruan memiliki pengaruh pada karakteristik nanopartikel ikan haruan yaitu ukuran partikel. Penambahan volume ekstrak pada formula dengan konsentrasi ekstrak yang sama akan terjadi peningkatan ukuran partikel nanopartikel.
\end{abstract}

Kata kunci: nanopartikel, gelasi ionik, kitosan, ikan haruan

\section{Outline}

- Pendahuluan

- Metode

- Hasil dan Pembahasan

- Kesimpulan

- Ucapan Terima Kasih

- Daftar Pustaka 


\section{Pendahuluan}

Ikan haruan merupakan salah satu ikan air tawar yang banyak digemari masyarakat Kalimantan Selatan. Ikan haruan memiliki nilai gizi yang tinggi ${ }^{3}$, serta dipercaya masyarakat suku banjar dalam membantu proses penyembuhan luka. Ekstrak ikan haruan memiliki sifat hidrofilik dan stabilitas yang rendah ${ }^{1}$. Sediaan nanopartikel dapat meningkatkan stabilitas dari komponen tersebut. Ada beberapa metode pembuatan nanopartikel, salah satunya adalah metode gelasi ionik.

Gelasi ionik merupakan metode yang cukup sederhana, karena tidak menggunakan pelarut organik, dan dapat dikontrol dengan mudah sehingga kemungkinan rusaknya bahan aktif dapat dicegah ${ }^{2}$.

Pada penelitian ini dilakukan berbagai variasi konsentrasi dan variasi volume penambahan ekstrak ikan haruan (Channa striata) ke dalam formulasi nanopartikel kitosan $0,2 \%$ dan TPP $0,1 \%$ untuk menentukan pengaruh terhadap karakteristik nanopartikel yang dihasilkan yaitu ukuran partikel, distribusi ukuran partikel, indeks polidispersitas, dan pengendapan.

\section{Metode}

\section{A. Bahan}

Bahan-bahan yang digunakan untuk ekstraksi ikan haruan (Channa striata) dan preparasi nanopartikel adalah ikan haruan (Channa striata), akuades, air deionisasi, asam asetat glasial, kertas saring Whatman No. 41, kitosan ,dan natrium tripolifosfat.

\section{B. Metode}

1. Preparasi Nanopartikel

a. Pembuatan Larutan Kitosan $(0,2 \%)$

Serbuk kitosan $0,2 \mathrm{~g}$ dilarutkan dalam $100 \mathrm{ml}$ larutan asam asetat glasial $1 \%$. Larutan asam asetat glasial diperoleh dari dengan cara melarutkan $1 \mathrm{ml}$ asam asetat glasial dalam $100 \mathrm{ml}$ akuades dan dilakukan pengadukan dengan menggunakan pengaduk magnetik. Larutan kitosan disonikasi selama 30 menit dengan suhu \pm $50^{\circ} \mathrm{C}^{1}$.

b. Pembuatan Larutan Natrium Tripolifospat $(0,1 \%)$

Serbuk natrium tripolifosfat $0,1 \mathrm{~g}$ dilarutkan dalam $100 \mathrm{ml}$ air deionisasi, dan dilakukan pengadukan menggunakan pengaduk magnetik.

c. Pembuatan Larutan Ekstrak Ikan Haruan (Channa striata)

Ekstrak ikan haruan ditimbang $200 \mathrm{mg}, 400 \mathrm{mg}$, dan $600 \mathrm{mg}$, dilarutkan dalam 100 $\mathrm{ml}$ akuades, dilakukan pengadukan dengan pengaduk magnetik hingga terlarut sempurna.

d. Pembuatan Nanopartikel Kitosan-Tripolipospat

Rasio volume kitosan dan natrium tripolifosfat yang digunakan adalah 5:1.Formula nanopartikel ikan haruan (Channa striata) dengan rasio ekstrak dan kitosan ditunjukkan pada Tabel 1.

2. Karakterisasi Nanopartikel

a. Penetapan Ukuran Partikel dan Distribusi Ukuran Partikel

Penetapan ukuran partikel dan distribusi ukuran partikel diukur dengan menggunakan Particle Size Analyzer (PSA). 


\section{b. Pengamatan Kejernihan}

Nanopartikel ekstrak ikan haruan (Channa striata) diamati kejernihannya secara visual dengan mengamati sistem opalescent yang terbentuk.

Tabel 1. Formula Nanopartikel Kitosan-Tripolipospat dengan Ekstrak Ikan Haruan

\begin{tabular}{|c|c|c|c|c|}
\hline Formula & $\begin{array}{c}\text { Konsentrasi } \\
\text { Ekstrak Haruan }\end{array}$ & $\begin{array}{c}\text { Volume Ekstrak } \\
\text { lkan Haruan }\end{array}$ & $\begin{array}{c}\text { Volume Kitosan } \\
(\mathbf{0 , 2} \%)\end{array}$ & $\begin{array}{c}\text { Volume Natrium } \\
\text { Tripolipospat } \mathbf{0 , 1 \% )}\end{array}$ \\
\hline 1 & $2 \mathrm{mg} / \mathrm{ml}$ & $5 \mathrm{ml}$ & $5 \mathrm{ml}$ & $1 \mathrm{ml}$ \\
\hline 2 & $4 \mathrm{mg} / \mathrm{ml}$ & $5 \mathrm{ml}$ & $5 \mathrm{ml}$ & $1 \mathrm{ml}$ \\
\hline 3 & $6 \mathrm{mg} / \mathrm{ml}$ & $5 \mathrm{ml}$ & $5 \mathrm{ml}$ & $1 \mathrm{ml}$ \\
\hline 4 & $2 \mathrm{mg} / \mathrm{ml}$ & $1 \mathrm{ml}$ & $5 \mathrm{ml}$ & $1 \mathrm{ml}$ \\
\hline 5 & $4 \mathrm{mg} / \mathrm{ml}$ & $1 \mathrm{ml}$ & $5 \mathrm{ml}$ & $1 \mathrm{ml}$ \\
\hline 6 & $6 \mathrm{mg} / \mathrm{ml}$ & $1 \mathrm{ml}$ & $5 \mathrm{ml}$ & $1 \mathrm{ml}$ \\
\hline 7 & - & - & $5 \mathrm{ml}$ & $1 \mathrm{ml}$ \\
\hline
\end{tabular}

\section{Hasil dan Pembahasan}

Analisis data pada penelitian ini dilakukan dengan analisis data secara deskriptif. Data evaluasi ukuran partikel dan pengamatan organoleptis dievaluasi secara deskriptif.

\section{A. Hasil}

Hasil penentuan ukuran partikel dengan penambahan $1 \mathrm{ml}$ ekstrak ikan haruan dengan variasi konsentrasi $2 \mathrm{mg} / \mathrm{ml}, 4 \mathrm{mg} / \mathrm{ml}$, dan $6 \mathrm{mg} / \mathrm{ml}$ menghasilkan nanopartikel dengan ukuran partikel $318,5 \mathrm{~nm}, 361,1 \mathrm{~nm}$, dan $403,5 \mathrm{~nm}$. Terdapat peningkatan ukuran nanopartikel ikan haruan pada penambahan $5 \mathrm{ml}$ volume ekstrak ikan haruan yaitu 1679,3 nm, $1114 \mathrm{~nm}$ dan $1554 \mathrm{~nm}$. Distribusi ukuran partikel berdasarkan nilai indeks polidispersitas semua formula memiliki nilai Pdi $<0,7$ menunjukkan bahwa nanopartikel ikan haruan yang dihasilkan monodisperse. Pada pengamatan kejernihan secara visual selama 7 hari tidak terjadi pengendapan.

\section{B. Pembahasan}

Ikan haruan yang digunakan dalam penelitian ini merupakan ikan haruan yang hidup liar di perairan rawa di kecamatan Kandangan Kabupaten Hulu Sungai Selatan (HSS) provinsi Kalimantan Selatan. Identifikasi sampel ikan haruan dilakukan di Balai Budidaya Ikan Tawar (BBAT) Mandiangin Kalimantan Selatan.

Fillet ikan haruan (Channa striata) diekstraksi menggunakan pressure cooker selama 45 menit 1. Pada preparasi nanopartikel kitosan-tripolipospat dengan ekstrak ikan haruan (Channa striata) digunakan kitosan dan natrium polipospat sebagai bahan pembentuk nanopartikel. Kitosan dipilih karena memiliki sifat mukoadhesif, biokompatibel, biodegradable, nontoksik, dan tingkat imunogenisitas yang rendah ${ }^{6}$. Sedangkan natrium tripolipospat memiliki sifat tidak toksik, dapat membentuk ikatan sambung silang dengan kitosan, nanopartikel yang didapat lebih stabil, dan memiliki karateristik penembusan membran yang lebih baik ${ }^{4}$.

Pada hasil penentuan ukuran partikel, perbedaan konsentrasi ekstrak memiliki pengaruh terhadap ukuran nanopartikel yang dihasilkan. Peningkatan konsentrasi pada F4, F5, dan F6 ukuran partikel akan semakin meningkat yaitu $318,5 \mathrm{~nm}, 361,1 \mathrm{~nm}$, dan 403,5 nm. Namun, hasil pengukuran F4, F5, dan F6 didapatkan ukuran nanopartikel yang lebih kecil apabila dibandingkan dengan formula lainnya. Pengaruh penambahan 
volume ekstrak terhadap peningkatan ukuran partikel yang dihasilkan dapat terlihat pada Gambar 1.

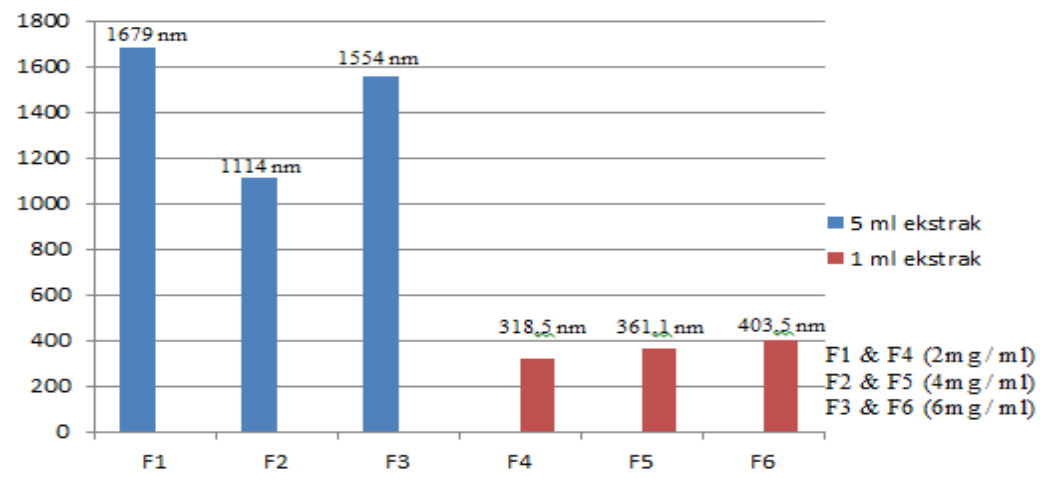

Gambar 1. Pengaruh penambahan volume ekstrak terhadap peningkatan ukuran partikel

F1 dengan F4, F2 dengan F5, dan F3 dengan F6 merupakan formula yang memiliki konsentrasi sama namun berbeda volume ekstrak yang ditambahkan. Penambahan volume ekstrak pada formula dengan konsentrasi yang sama akan terjadi peningkatan kandungan ekstrak ikan haruan yang terkandung dalam nanopartikel dan menyebabkan peningkatan ukuran partikel 7. F1 $(2 \mathrm{mg} / \mathrm{ml})$ dengan penambahan $5 \mathrm{ml}$ ekstrak menghasilkan ukuran 1679,3 nm, F4 (2mg/ml) dengan $1 \mathrm{ml}$ ekstrak menghasilkan ukuran $318,5 \mathrm{~nm}$. F2 $(4 \mathrm{mg} / \mathrm{ml})$ dengan penambahan $5 \mathrm{ml}$ ekstrak menghasilkan ukuran $1114 \mathrm{~nm}, \mathrm{~F} 5(4 \mathrm{mg} / \mathrm{ml})$ dengan penambahan $1 \mathrm{ml}$ ekstrak menghasilkan ukuran 361,1 $\mathrm{nm}$. F3 $(6 \mathrm{mg} / \mathrm{ml})$ menghasilkan ukuran $1554 \mathrm{~nm}$, F6 $(6 \mathrm{mg} / \mathrm{ml})$ dengan penambahan ekstrak $1 \mathrm{ml}$ menghasilkan ukuran 403,5 nm. Volume yang ditambahkan dapat meningkatkan jumlah partikel, karena adanya interaksi antara partikel menyebabkan partikel mengumpal, partikel yang menggumpal mudah mengendap dan membentuk partikel yang lebih besar.

Indeks polidispersi (Pdi) menggambarkan distribusi ukuran partikel nanopartikel. Nilai indeks polidispersitas yang masuk dalam rentang monodispersi adalah dalam rentang 0,01-0,7 sedangkan untuk nilai indeks polidispersitas yang masuk dalam kategori polidispersi adalah $>0,7^{5}$. Hasil pengukuran indeks polidispersi dapat diliat dari tabel 2 . Nilai indeks polidispersitas formula $1,2,3,4,5,6$, dan 7 secara berturut-turut yaitu 0,$201 ; 0,560 ; 0,560 ; 0,452 ; 0,552 ; 0,529$; dan 0,404. Hasil tersebut menunjukkan bahwa nanopartikel yang dihasilkan monodispers. Hasil indeks polidispersi yang dihasilkan pada penelitian $<0,7$.

Tabel 2. Hasil Pengukuran Indeks Polidispersi

\begin{tabular}{|c|c|c|}
\hline Formula & Ukuran Partikel $(\mathrm{nm})$ & Indeks Polidispersi \\
\hline F1 & 1679,3 & 0,201 \\
\hline F2 & 1114 & 0,560 \\
\hline F3 & 1554 & 0,560 \\
\hline F4 & 318,5 & 0,452 \\
\hline F5 & 361,1 & 0,552 \\
\hline F6 & 403,5 & 0,529 \\
\hline F7 & 454,7 & 0,404 \\
\hline
\end{tabular}

Nanopartikel kitosan-tripolipospat yang ditambahkan ekstrak ikan haruan diamati kejernihannya secara visual selama 7 hari. Pengamatan uji kejernihan dapat dilihat 
pada tabel 3. Berdasarkan tabel 3, pengamatan uji kejernihan F4, F5, F6, dan F7 hari ke-1 sampai hari ke-6 tidak terjadi pengendapan dalam larutan nanopartikel.

Tabel 3. Hasil pengamatan kejernihan hari ke-1 hingga hari ke-7

\begin{tabular}{|c|c|c|c|c|c|c|c|}
\hline Formula & Hari 1 & Hari 2 & Hari 3 & Hari 4 & Hari 5 & Hari 6 & Hari 7 \\
\hline F4 & - & - & - & - & - & - & - \\
\hline F5 & - & - & - & - & - & - & - \\
\hline F6 & - & - & - & - & - & - & - \\
\hline F7 & - & - & - & - & - & - & - \\
\hline
\end{tabular}

Keterangan: (-)Tidak ada endapan (+)Terdapat endapan

\section{Kesimpulan}

Kesimpulan yang dapat diperoleh dari penelitian ini adalah variasi konsentrasi ekstrak dan variasi volume ekstrak ikan haruan memiliki pengaruh pada karakteristik nanopartikel ikan haruan yaitu ukuran partikel. Penambahan volume ekstrak pada formula dengan konsentrasi ekstrak yang sama akan terjadi peningkatan ukuran partikel nanopartikel.

\section{Ucapan Terima Kasih}

Penelitian ini dapat terlaksana atas dukungan Dana Hibah Penelitian Kerjasama Perguruan Tinggi KEMENRISTEK DIKTI. Peneliti menyampaikan terimakasih khusus kepada Prof. Effionora Anwar, M.S. (Universitas Indonesia) atas sharing ilmu dan bimbingannya dalam pelaksanaan penelitian

\section{Daftar Pustaka}

1. Ahdyani R. 2015. Preparasi dan Karakterisasi Nanopartikel Albumin Ikan Haruan (Channa striata) Asal Kalimantan Selatan Dengan Metode Gelasi lonik. Skripsi Fakultas Matematika dan IImu Pemgetahuan Alam, Universitas Lambung Mangkurat.

2. Agnihotri S.A., Mallikarjuna N.N., Aminabhavi T.M.. 2004 Recent Advances on Chitosan-based Micro and Nanoparticles in Drug Delivery, Journal of Controlled Release, 100, 5-28.

3. Cahyana, S. P. D. 2013. Ikan Gabus di Kancah Nasional. Badan Litbang Pertanian. Banjarmasin.

4. Iswandana, R. 2012. Preparasi Nanogel Verapamil Hidroklorida Menggunakan Metode Gelasi Ionik antara Kitosan-Natrium Tripolifosfat sebagai Sediaan Antihipertensi. Tesis, Fakultas Matematika dan IImu Pengetahuan Alam, Universitas Indonesia. Depok.

5. Nidhin, M., Indumathy, R., Sreeram, K. J., dan Nair, B. N. 2008. Synthesis of Iron Oxide Nanoparticles of Narrow Size Distribution on Polysaccharide Templates. Bull. Mater. Sci, 31, 93-96

6. Sinko, \& Singh, 2011. Martin Farmasi Fisika dan Ilmu Farmasetika edisi 5, diterjemahkan oleh Tim Alih Bahasa Sekolah Farmasi ITB, 706, Penerbit Buku Kedokteran EGC, Jakarta.

7. Wu, Y., Yang, Wang, C., Hu, J., dan Fu, S., 2005. Chitosan Nanoparticles as A Novel Delivery System for Ammonium Glycyrrhinate, International Journal of pharmaceutics, 295, pp 235-245. 